\title{
TYPES AND WAYS OF MODERNIZATION IN A CONTEXT OF THE INTERNATIONAL EXPERIENCE
}

\author{
Nataliia Vodolazskaya
}

\begin{abstract}
Results of the researches of productive and economic systems of a number of the countries are stated in this paper. Types and ways of modernization of these systems taking into account the choice of the development model of a society are presented. Process regularity of international modernization, including Russia is specified. The immediacy of the problem of modernization as sets of technological, economic, cultural, political changes is proved. The listed changes are directed towards the improvement of social system, culturaleducational level of the population, and towards the increase in prestige of the country in general. Qualitative differences between the eastern ("Asian") and western ("European") ways of modernization are given. The objective reasons for differences in character, rates, efficiency of implementation of political modernization in post-socialist societies are the level of political stability in society, presence of the reformatory elite interested in political and innovative development strategies of society and cultural traditions. Stages and prerequisites of production modernization are considered. The problems describing participants of the process, their competences and professional standards are shown. The quality of education of the leading representatives was and remains the major indicator defining long-term development of a society. Examples of implementation of the international educational projects are given.
\end{abstract} Keywords: modernization, productive and economic systems, society, international process JEL Classification: D83, E27, F59, L52, O21, P41

\author{
Author(s): \\ Nataliia Vodolazskaya \\ Federal State Budgetary Educational Institution of Higher Education "Belgorod State Agricultural \\ University named after V. Gorin”, 1, Vavilova Street, Mayskiy, Belgorodskaya Region, Russia, 308503 \\ E-mail:vnv26@bk.ru \\ https://orcid.org/0000-0002-1168-5741
}

Citation: Vodolazskaya, N. (2019). Types and ways of modernization in a context of the international experience. Virtual Economics, 2(1), 82-98. https://doi.org/10.34021/ve.2019.02.01(5)

Received: September 3, 2018. Revised: October 16, 2018. Accepted: December 6, 2019.

(C) Author(s) 2019. Licensed under the Creative Commons License - Attribution 4.0 International (CC BY 4.0) 


\section{Introduction}

The international process of formation of the economic relations in the conditions of globalization of the world market faces a number of problems, considering branch and regional functioning features of production systems of the various states. Therefore, researches of such systems are of the special urgency. They allow to implement ecological production modernization taking into account a choice of the development model of the society. Modernization represents a set of technological, economic, cultural, political changes which are directed towards the improvement of social system, cultural and educational level of the population and the increase of prestige of the country as a whole. Thus it should be noted that practically all societies have an ability to the updating and they aspire to achieve steady competitiveness with other organized societies. As a rule, in the international practice of historical development this process occurs within internal structure of the most developed social system. Natural character of gradually developing modernization is caused by the processes of self-control of the society which assumes the improvement of requirements and development of new skills of their satisfaction.

Modernization as a fundamental problem consists of narrower problems. For less developed countries, economic modernization means overcoming their backwardness. Actually it can be presented as an attempt to catch up with the developed countries on the level of economic development. Therefore, the term catching-up development has appeared. For the developed countries, modernization means, first of all, the solution of the problems which are characteristic of a post-industrial stage of development - they are the problems of the human capital, innovations, financial stability, international competitiveness.

\section{Literature review}

The research (Kryuchkov et al., 2014) carried out by a number of Russian scientists has shown that a process of modernization exists in all spheres of the person's activity in spite of the fact that in scientific community there is no uniform position about an effective vector of its development (Burenko \& Shumilov, 2012). On the basis of the analysis of socio-political and economic development of the country, Russian political scientists V.I. Burenko, Z.V. Ivanovskiy, V. G. Ledyaev, L.G. Titova, O.F. Shabrov, etc. prove the thesis about formation of rather stable political system which at last was transformed from a negative situation of the end of the last century when there were no standard and legal bases for implementation of reforms (Kryuchkov et al., 2013). German scientist X.Steiner (Steiner, 2003) allocated three groups of the countries differing in historical specifics and modern development.

The first group are the countries of the Central Europe and the Baltic States (Poland, Hungary, the Czech Republic, Slovenia, Slovakia, Estonia, Latvia) which by the time of entry into the modern world system reached rather high level of social, economic and political development. After receiving the independent status, having considerably democratized the political power and having rehabilitated private property, these countries took the most thorough steps to the development of civil society and stayed on the road of successful political modernization. The 
second group are the countries of Central, Eastern and Southeastern Europe (Albania, Bulgaria, Romania, and also the majority of the countries resulted from the disintegration of Yugoslavia) which had rather low level of socio-economic and political development before the establishment of socialism. Having gained the state independence, these countries have carried out political modernization slowly and ineffectively. The third group are the Post-Soviet countries which passed a way of the state socialism within the USSR (Georgia, Russia, Ukraine, Uzbekistan, etc.) which were middle-advanced in socio-economic and socio-political aspects. Having found sovereignty, these states took the way of the political modernization, urged to replace the system of the Soviet type democratic political system. However, the directions of the valid changes in the Post-Soviet states often do not correspond to the vectors of reforms wished or declared by the political elite. Their created institutes of the political power are far from a liberal and democratic ideal to which they aspired (Burenko, 2012). At the end of the XX century R. Rose, K.Herpfer and V. Mishler by the results of the research program of Society of Paul Lazarsfeld «New democratic barometer» also came to a conclusion about a divergence of the ways of post-socialist development. From the point of view of democracy and action manifestation of a post-totalitarian system factor, the authors allocated three groups of the countries - "leading", "late" and "Post-Soviet" which according to their structure practically coincide with the typology offered by X. Steiner taking into account a wider set of factors (Kutsenko, 2004). The objective reasons for differences in character, rates, efficiency of implementation of political modernization in post-socialist societies are the first level of political stability in society, secondly, existence of the reformatory elite interested in political and innovative strategy of the development of society, thirdly, the accounting of cultural traditions.

At the same time, there are also opinions that the Soviet period cannot be considered through the prism of the theory of modernization (Maksimova \& Lyamtseva, 2011). The socialism is characterized as antimodernization structure or as false modernization (The Russian modernization, 1993). Stagnation in political system at the rapid development of industrialization is interpreted as the indicator of false modernization. In particular, the Polish sociologist P. Sztompka on the example of the USSR and communist countries of Eastern Europe showed that the elements of the above-mentioned imposed to society by the authoritative power are fancifully combined with the heritage of premodern eras covered with symbolical substitutes of institutional modernization. In this sense, according to the author, socialist modernization is imaginary since there was only an imitation of changes in political systems of the socialist camp states (Sztompka, 1994).

In scientific literature the modernization possibilities of the power are often estimated through its influence on the political stability of society. In effect, political stability is defined as absence of structural changes in political system of society or control possibility over these changes; as result of legitimacy of the power; as behavior model when people regulate the behavior by a certain code of morals and political actions, understanding that the deviation from these codes leads to instability in society (Kryuchkov et al., 2014). Therefore, to begin cardinal sociopolitical transformations, it is important to stabilize the political situation. 
The specified tendencies explaining regularities of modernization processes in international and (including Russian) national contexts differ concerning the concrete countries and the people by the degree of the intensity and the advance. Professor G.N. Lanskoy suggests to designate the arising distinctions, proceeding from the contents, as the ways of modernization (Lanskoy, 2018).

The first way of modernization was realized by the countries relating to the western type of civilizations and it had consecutive linear character. The West European way of modernization assumed in the beginning the transformation of political system of society and respectively an ideological platform of its development. As a rule, such transformation was rather radical as it concerned redistribution of imperious functions as well as the status of privileges and available public benefits. Those countries and societies were the first on the way of structural political changes in which social and economic progress appeared to be the most successful and consecutive. Such practice and sequence of changes were traced in Great Britain and France. Later it happened in Germany and in the USA, which were formed in essence as the countries accumulating optimum traditions of modernization and personnel reserves from other countries.

The second way of modernization was peculiar to the countries relating to the eastern type of civilizations. Japan, India and China (China, 2009) are the most advanced of them. In these countries complex changes of social system appeared the most considerable. Obvious actual distinctions exist between historical practices of development of these countries (for example, China passed through a stage of existence of a totalitarian and communist mode; India was in the colony status for centuries). But they have the general properties of internal transformation. There are political and economic changes for achievement of sufficient competitiveness and at the same time preservation of own historically developed traditions of spiritual culture and mentality. Any penetrations of new traditions (for example, during "opium" wars in Southeast China) were dissolved sooner or later in the affirmed cultural shape and disappeared practically without a trace.

Qualitative differences between eastern ("Asian") and western ("European") ways of modernization were repeatedly emphasized in historical and sociological researches (Lanskoy, 2018). These representations began to change only in the last decade taking into account considerable achievements of China, Japan, India and to a lesser extent other countries (for example, Koreas). Consequently, successes in the area of modernization of economic system can be provided also in the alternative directions in relation to the European tradition.

Therefore, the choice of one of two considered above ways of modernization has conceptual character according to the contents and strategies. It defines the role and the status choosing for itself the program of transformations of the country in the system of the international relations. To a considerable degree, this choice depends on the resource, and mental and psychological (including manifestation of historical memory) potential which public institutes and groups operating in the territory of the country possess. 
The purpose of this work is to give the characteristic of some existing models of modernization and to offer methodological models which can be applied in the context of national and international modernization. Besides, it will elucidate more fully the evolution of a modernization paradigm and will plan the possible prospects of its further development.

\section{Methodology}

The designated subjective circumstances are characteristic for the present stage of modernization of Russia along with naturally remaining objective factors. It is important to emphasize the existence of high level of government legitimacy in the country, legitimacy of the leaders heading these departments and the public organizations, giving ideological support to the administrative structures of personnel. Sources of legitimacy are the norms of a constitutional law defining the system of authority's interaction; the status of the state head as the guarantor of execution of the main legislative decisions; wide volume of functions of the federal ministries and the departments, strengthening of the territorial organization of the state; existence of the ruling party having universal support of the social majority. Existence of the strong administrative base of modernization faces only one risky functional form of the development when the state loses communication with society at the level of identification and the lists of its updated requirements. Lack and disappearance of such communication have already repeatedly caused crises including revolutionary processes for the Russian statehood. Thus, patriotism and adherence of certain idealistic (Christian or communistic) concepts are red lines of development including modernizations of Russia throughout a long time.

These political and ideological changes have found their continuation in the economic sphere. Some authors focus attention on the economic aspect of modernization. So Walt Rostow in his work "A stage of economic growth» aspires to define the conditions necessary for start and further continuous accumulation of the capital and investments i.e. for continuous generating of the national profit. Modern Russian researchers (V.A. Krasilshchikov, G. Drach, S.Yu. Malkov, V. G. Fedotova) after foreign authors at the end of the $X X$ - the beginning of the XXI century came to a conclusion about the need of refusal of "catching-up modernization" in favor of national modernization on the basis of already reached results during the process of catchingup modernization (Krasilshchikov, 2009; Pain, 2008; Fedotova, 2009). As a result of modernization, a society gets the following characteristics in the economic sphere: prevalence of industrial technologies of mass production, labor market, the goods, finance, existence of conditions for economic growth and wellbeing of people. In other words, today the modernization of production structure of high-technological branches, science and education spheres as key factors of growth is one of the main conditions of a sustainable development of each state (Vodolazskaya, 2016; Vodolazskaya, 2018). Questions of economic and production modernization are undoubtedly actual and important for Russian Federation. However, now the given problem is not solved yet and it demands the fastest measures for current situation change.

The crisis phenomena in the world and national economies bared one of the main shortcomings of the Russian economic development. It is the specifics of the structural 
reproduction model characterized by the low competitiveness of the processing branches that leads to "a raw distortion" economy and to the relevant position in the world market. Existence of raw material resources is one of the key factors of the development for the state. But in a long-term prospect, the growth indicators of the countries possessing considerable resources appear worse than of the countries with similar level of the income per capita, but having smaller resources (Meshkov et al., 2017; Vodolazskaya, 2017; Matokhina et al., 2017). The theoretical basis which has united statistical data and researches of scientists on a perspective of effective use of resources was the concept of "a resource damnation." According to this concept "in the long term, the period of resources abundance cannot stimulate economic development, but only slow it down» (Shmyrova, 2010; Guriyev et al., 2010).

Today Russia is also in a similar situation. During the pre-crisis period the level of its social and economic development was characterized by quite high key indicators. So Russian gross domestic product in 1999-2008 grew by $93 \%$. However, statistical data did not reflect the valid situation, namely, the missed possibilities of modernization of national economy and its direction to a way of innovative development. Favorable conjunctural changes in the world markets of traditional Russian export became the main source of growth of gross domestic product in the XXI century for Russia. The income of export of raw materials and energy carriers only to insignificant degree was directed to the development of scientific and technical potential, updating of the fixed business assets, support of health care and social development. It was more concentrated on the stabilization fund placed abroad. Reduction of prices of oil in 2008 by more than 2 times caused falling of the Russian gross domestic product (from 9,3\% in the first quarter of the year 2008 to $0 \%$ in the fourth quarter) (Shmyrova, 2010; Indexes of physical volume, 2018). The power raw scenario of the development of the Russian economy is a deadlock and further development of the country is not obviously possible without modernization of the national economy, in particular, industrial modernization taking into account the development of the human capital in full. (Vodolazskaya, 2018).

Modernization of production can be complex (replacement of out-of-date units), partial (sector replacement) or a regeneration of systems or equipment at the enterprise (Vodolazskaya, 2016). This process involves careful information accumulation and analysis. It concerns both conditions of the production and studying of offers from suppliers of the equipment and services. As a whole, depending on the sizes of the enterprise, its financial possibilities and modernization plans, the introduction of these actions can take from several months to one year and a half.

As any process, modernization of production has some stages. The first three stages are directly connected with the analysis of all available information and statistical data. The choice of the equipment and suppliers also demands studying. Further efficiency and payback of the enterprise depends on quality and characteristics of the equipment. Reliability of suppliers influences speed of modernization and its cost. It is important to notice that the stage of search of the equipment and suppliers should begin at the same time with consideration of a problem of modernization need. It will allow to compare the current situation with prospects which the new equipment will give. Formation of the business plan will help to order the entire process and to calculate expenses and time of payback of the undertaken measures.

Mechanism of modernization presented on Fig. 1.

Nataliia Vodolazskaya

Virtual Economics, Vol. 2, No. 1, 2019 


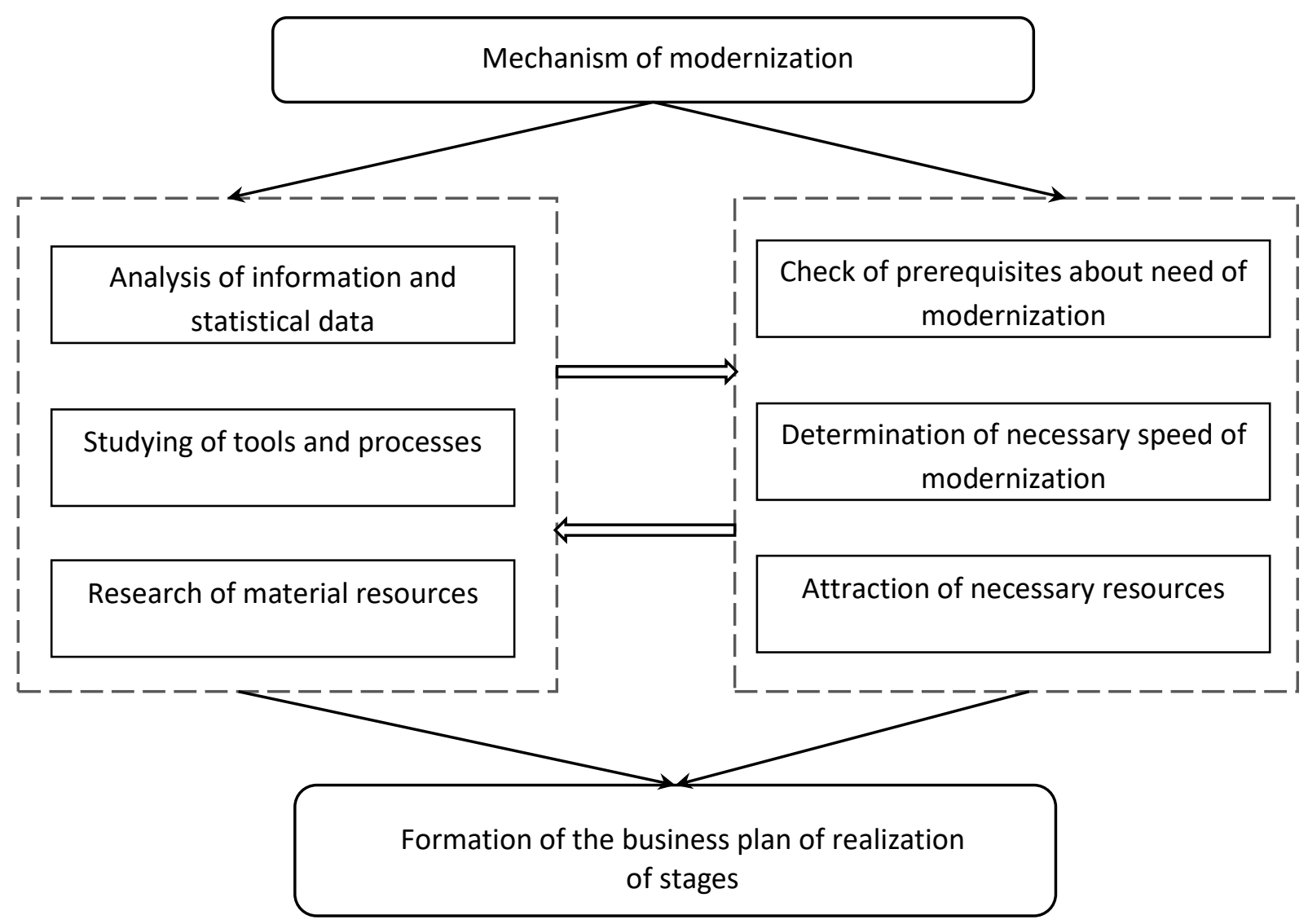

Figure 1. Mechanism of modernization Source: own research.

All preconditions presented in Fig. 2 are necessary for making decision on modernization.

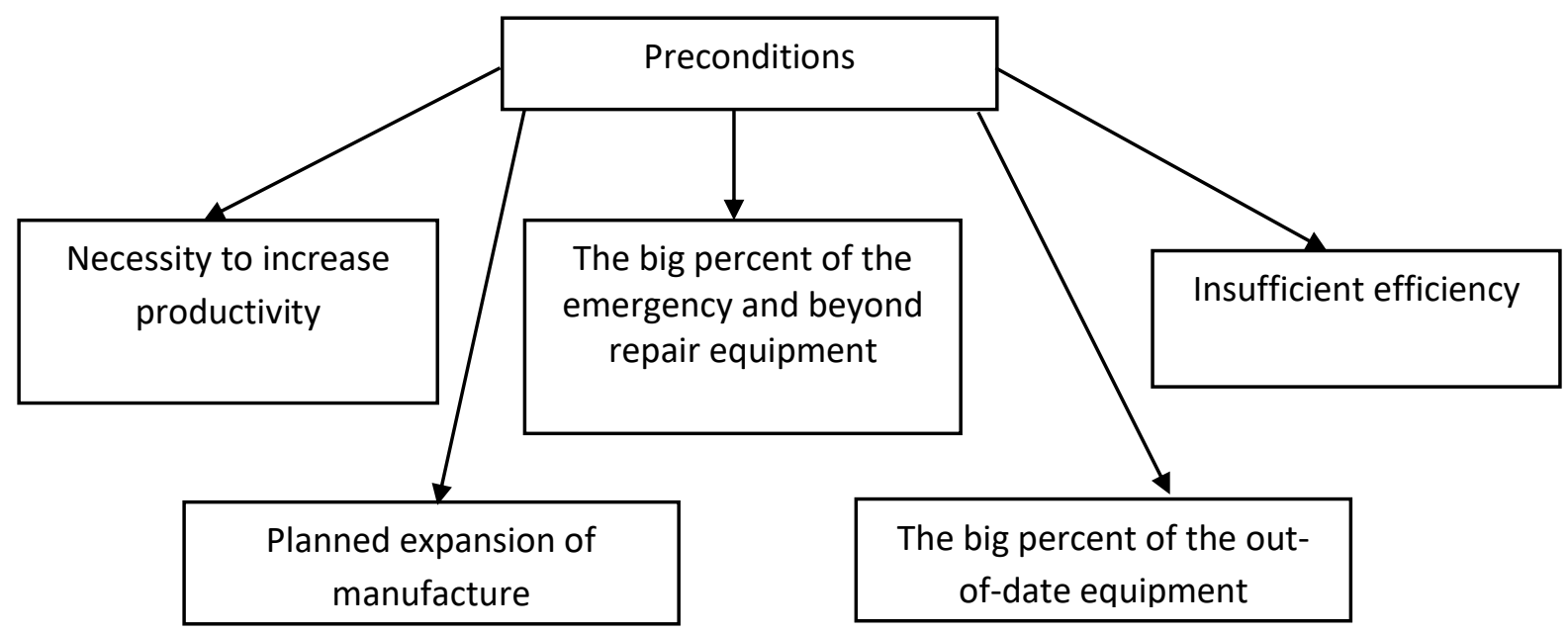

Figure 2. The scheme of preconditions for necessary modernization Source: own research. 
Modernization of production will demand attraction of credit resources. Seldom some enterprise presumes similar actions at own expense. Nevertheless, the contract can be concluded with suppliers without waiting loan opening. It is enough to receive confirmation of approval of inquiry from the creditor.

The longest stage is the supply of equipment. It can take some months. As a rule, different producers deliver equipment. They can be in the distance from the enterprise customer and sometimes in other country and even the continent.

Assembly occurs quickly (speaking about large enterprises - about one month). When equipment arrives, the enterprise already increases qualification of the personnel (Vodolazskaya, 2011; Vodolazskaya, 2012; Jasiak, 2015) or employs experts. Production modernization is usually finished by a stage of carrying out trial operation. It is necessary for identification of malfunctions and the subsequent final assembly (Vodolazskaya, 2009; Vodolazskaya \& Strebkov, 2017).

For example, some "Melitek" devices are the progressive equipment shown in Fig. 3. They are widely applied at production modernization, in particular, for quality control of the products made of different materials, for the control of raw materials, workpieces, details and also in the laboratories where new designs and materials (Melitek catalog, 2018) are developed. Industrial modernization of this type of the equipment provides high precision of measurements; wide range of possible loadings; simplicity and convenience of use; work possibility with samples of the various sizes; high reliability.

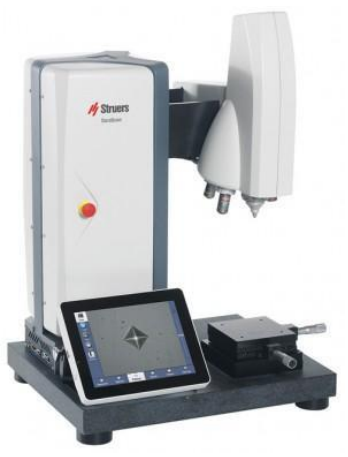

a)

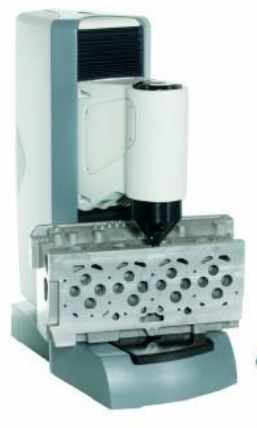

b)

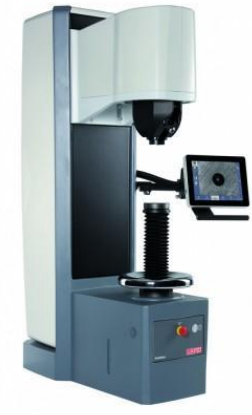

c)

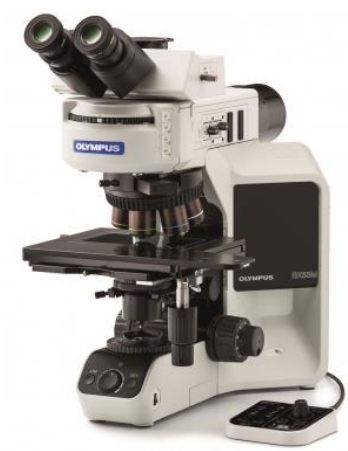

d)

Figure 3. Examples of modern types of the equipment for quality control of products:

a) microhardness tester DuraScan-20;

b) Rockwell hardness tester DuraJet;

c) universal hardness gage DuraVision-30;

d) upright microscope BX53M

Source: own research. 


\section{Results}

The analysis of the main types of modernization shows that modernization is not a complete logical structure, but rather a set of concepts of modern social development. And it allows to find the axial strategic directions of this development that coincide with the requirements of the sociological, economic, and political science spheres.

The results of modernization for a certain period of time are reflected in the coefficient of renewal of fixed fund by the sectors of the economy, including those related to high, medium, and low degree of manufacturability, which allows to assess the level of development and renewal of the material and technical base of the industry. It is shown in Fig. 4.

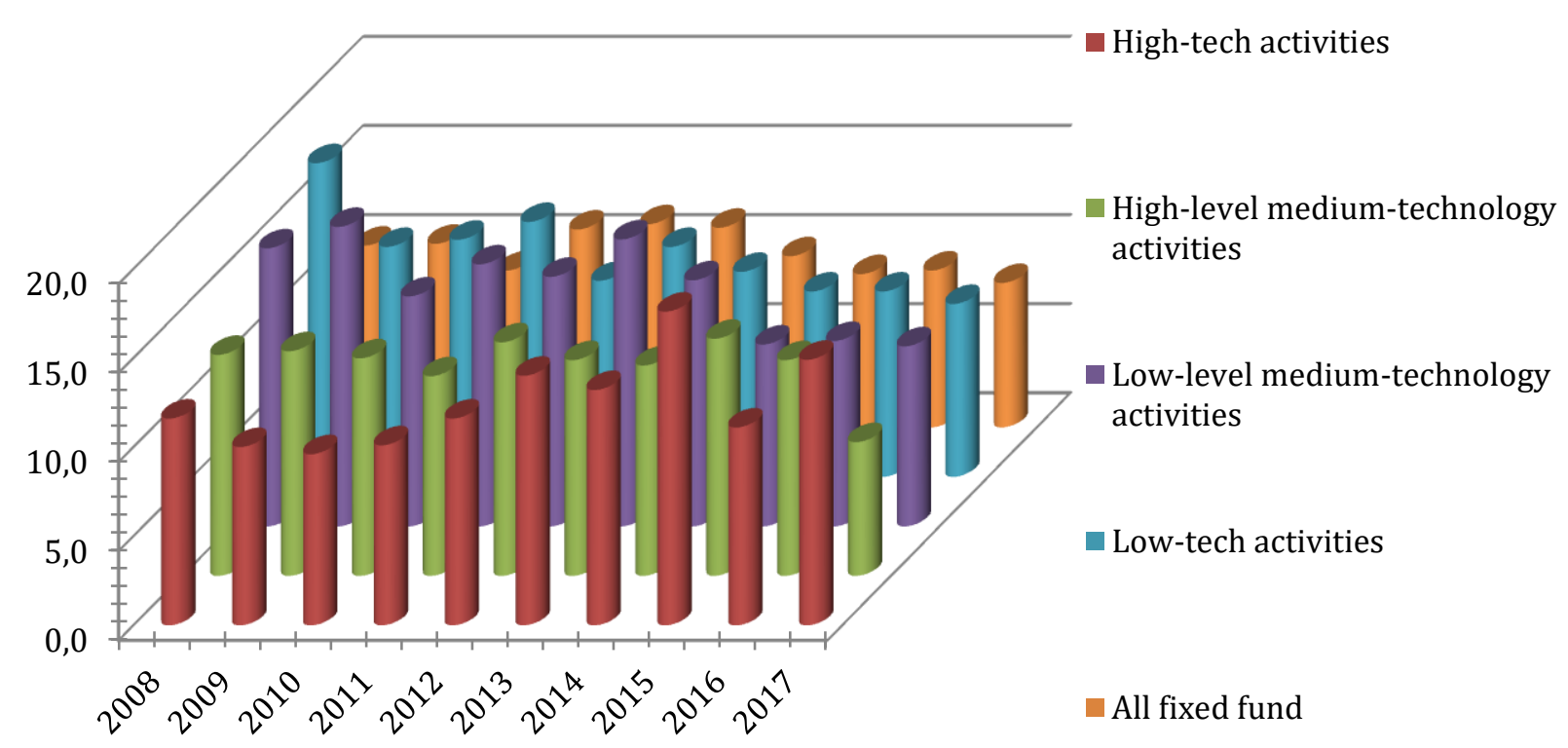

Figure 4. The coefficient of renewal of fixed fund according to the level of technology Source: own research on the basis of Russtat data.

Maximum values of coefficient for high-tech activities reached $17.6 \%$ in 2015, for medium-tech high levels of activity $-13.3 \%$ in 2015 , for medium-tech low activities $-17.6 \%$ in 2008 , for low technology activities - $16.1 \%$ in 2013. Decline in all sectors of the economy is in 2017, respectively - $14.9 \% ; 7.5 \% ; 10.1 \%$ and $9.7 \%$, which indicates the need for modernization.

On the other hand, the analysis of the depreciation degree of the fixed fund by industries shows a tendency to increase in almost all areas of economic activity. It is shown in Fig. 5 . The depreciation curve of all fixed assets continuously rises from 2008 - 43.4\% to $2017-49.5 \%$. Especially large readings are related to the branch of wholesale and retail trade; repair, motorcycles, and household appliances, reaching a value of $64.9 \%$ in 2017 . This indicator 
allows to assess the state of the material and technical base of industries. The depreciation rates for most sectors of the economy are approaching or exceeding $50 \%$, which is critical for the development of economic sectors and requires the adoption of appropriate measures to control the situation.

However, besides solving the problems of technical and economic aspects of the issue of modernization, it is necessary to pay attention to the direct participants of this process, their competencies and the level of professional qualifications. A quality of education of the leading society representatives is the major indicator defining long-term development of the society (Vodolazskaya \& Bondareva, 2016; Vodolazskaya, 2012). It is necessary to realize the system concept of a sustainable development for the solution of a problem of education modernization because traditional education does not always react to arising problems in due time (Meshkov et al., 2018; Lavrov et al., 2015; Sharaya \& Vodolazskaya, 2018). Formation of a sustainable development provides transition to focused economic and social model of training. It is based on the interdisciplinary knowledge and on a comprehensive approach to the development of the society (Faber, 2008; Victor, 2008; Zencey, 2005; Soderbaum, 2008). Unfortunately, investments into education, health care, science have long-term character as a rule.

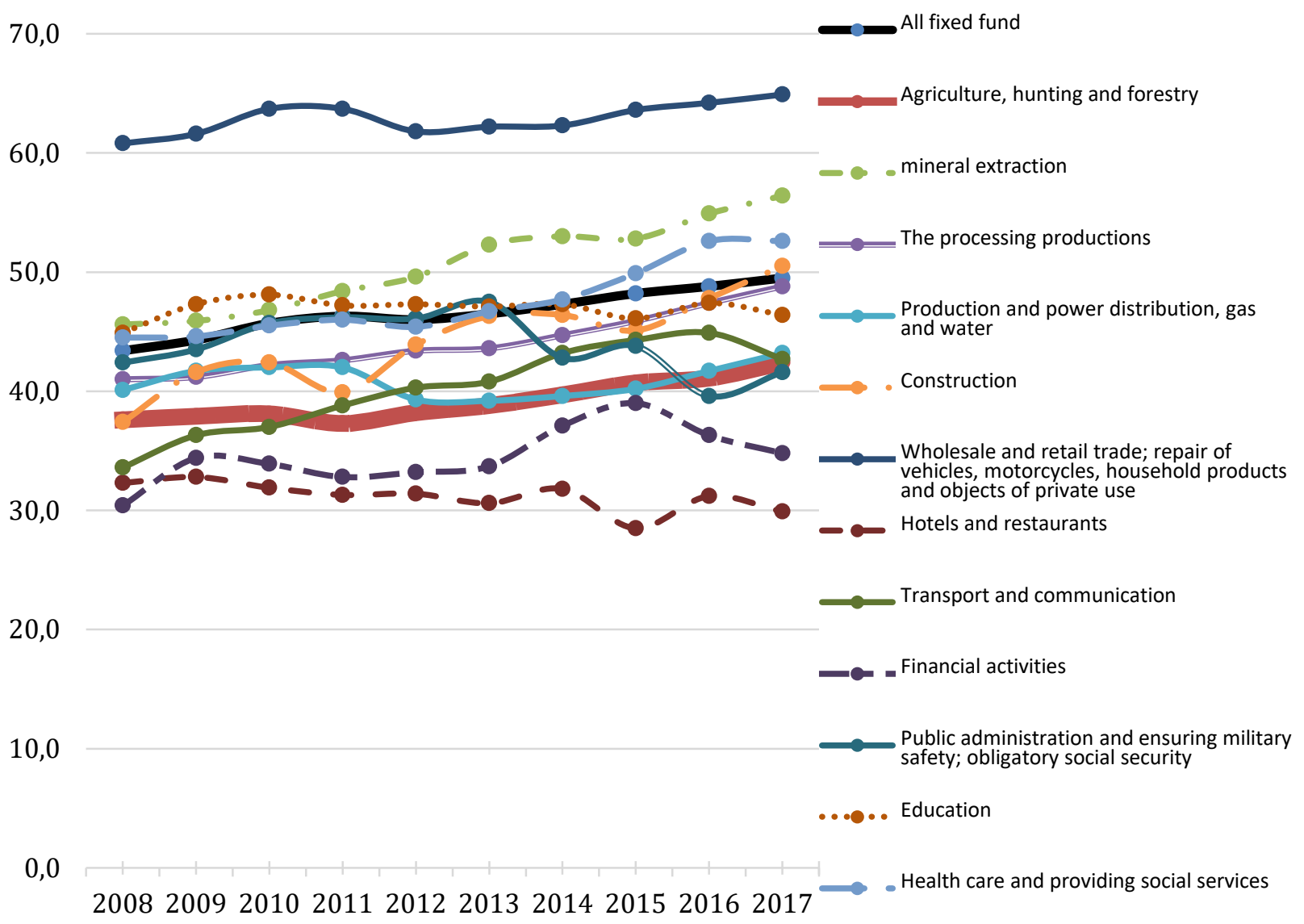

Figure 5. The coefficient of renewal of fixed fund according to the level of technology Source: own research on the basis of Russtat data. 
However, now Russian companies are more focused on receiving profit in the short-term period. And in these conditions, investment into the person becomes unprofitable for the vast majority of businessmen. These and other factors (low, in comparison with the leading countries of economic development, salary level, lack of worthy working conditions and labor reproduction) promote the phenomenon called brain drain.

Therefore, the problem of education modernization is the task of prime importance for educational institutions. It is directed not only towards the training of experts with a high skill level and professional mobility, but also towards high social responsibility. The need of employment according to the level of education of the population is presented in Fig. 6.

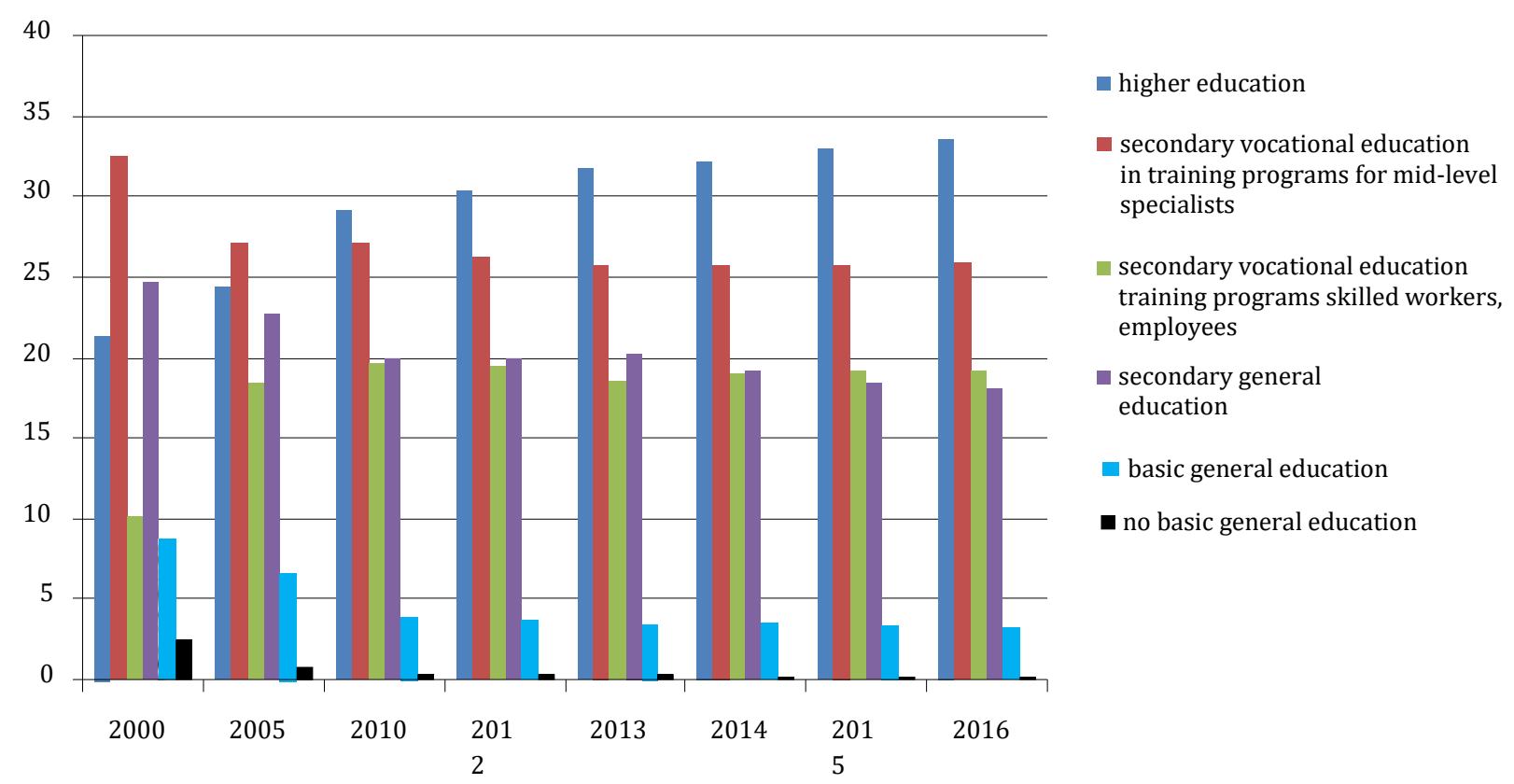

Figure 6. The need of employment according to the level of education of the population Source: own research on the basis of Education indicators, 2018.

The histogram shows that every year the need for highly qualified personnel increases: with higher education from $21.5 \%$ in 2000 to $33.5 \%$ in 2016, for secondary vocational education total (secondary vocational education in training programs for mid-level specialists and secondary vocational education training programs for skilled workers, employees) from $42.6 \%$ in 2000 to $45.1 \%$ in 2016.

Training of such professional staff that are capable to adequately react to the changing conditions of the global market results in the need of modernization of an education system. In this regard, the priority directions of state policy are the following:

- individualization of educational process and the educational programs considering interests and abilities of the personality;

- ensuring competitive education level; 
- training in the basic principles of creation of professional career and skills of behavior in a labor market;

- the organization of educational process taking into account modern achievements of science;

- creation of the programs realizing information technologies in education and development of open education;

- academic mobility of students;

- training of the highly qualified personnel capable of the professional growth and professional mobility in the conditions of informatization of society and development of new high technologies.

For a long time, a pedagogical internship exists in the developed countries (Gracheva, 2011; Faskhutdinov, 2015). The analysis of its organization allows to define the following general positive tendencies:

- improvement of quality of teaching;

- prevention of outflow of perspective beginning teachers;

- assistance to personal and professional growth of the beginning teacher;

- satisfaction of need of the concrete school district in teachers;

- successful advance of the teacher from a survival phase to a phase of complete adaptation;

- providing conditions of gradual occurrence into a profession.

Within the project modernization, special educational programs are used in some higher educational institutions of Russia (Simonova \& Minyurova, 2015; Margolis \& Rubtsov, 2011). They are directed to the training of specialists who possess the professional competences necessary for implementation of the effective management of groups (including virtual) consisting of representatives of various cultures. The need for such experts is defined by entry of Russia into the world community and expansion of international relations in various spheres (Vodolazskaya, 2017). The graduate of an educational program can carry out professional activity in the polycultural environment, considering features of a sociocultural situation of development (Simonova \& Minyurova, 2015; Bolotov, 2014). Training is realized in virtual space specially created by means of modern information technologies. There are groups of students of partner universities together in that space. A working language of an educational program is English. Practice of using of the international virtual educational projects allows to reach qualitatively new level of the organization of educational process. There is a creation of the enriched educational space. It provides the university with the experience of real intercultural interaction and forms students' important competences (Minyurova, 2015). However, it is worth to remember about the need of preservation of the best domestic educational traditions (Simonova \& Minyurova, 2015). Throughout centuries they were distinctive and strong side of the Russian system of higher education.

Thus, the appeal to the international experience of using modernization projects can have comprehensive advantage for the definition of a further course of development of modern Russia. 


\section{Conclusions and directions of further researches}

Unreasonable mixture of different groups, types, subspecies of modernizations is allowed sometimes in scientific literature. Classical and modern versions of the modernization analysis differ significantly. At the same time, it should be noted that there is a certain progress in the development of activity approach. It is perspective for the improvement of a modernization paradigm.

Modern Russia takes some intermediate place. It exists in an inertial state between authoritarianism and free competition, between the leading and catching up modernization, between the West and the East.

Russia should make use of the accumulated experience of the countries using positive models (types and ways) in the sphere of modernization of economy and technologies for further development.

As the directions of future researches it is supposed to consider the following problems:

- development and creation of such system of professional education at which university graduates would be capable to carry out functions without retraining and professional development;

- exit of system of Russian education from under blind humility to foreign models with orientation to the interests of residents of the country, a domestic education system.

\section{References}

Bolotov, V. A. (2014). K voprosam o reforme pedagogicheskogo obrazovaniya [To questions on pedagogical education reform]. Psikhologicheskaya nauka i obrazovanie - Psychological science and education, 19(3), 32-40 [in Russian].

Bondarenko, N. V., Gokhberg, L. M., Kovalyova, N.V., \& etc. (2018). Education indicators: 2018: statistical collection. Moscow: Higher School of Economics Publishing House.

Burenko, V. I. (2012). O politicheskoy modernizatsii v sovremennoy Rossii v kontekste osobennostey ee pravyashchego klassa [About political modernization in modern Russia in the context of features of ruling class]. Vestnik Universiteta (Gosudarstvennyy universitet upravleniya) - Bulletin of the University, 17, 9-14 [in Russian].

Burenko, V. I., \& Shumilov, A. V. (2012). Politicheskiy klass sovremennoy Rossii v kontekste instrumental'nogo podkhoda [Political class of modern Russia in the context of tool approach]. PolitBook, 4, 9-18 [in Russian].

China: universal model of modernization? (2009). Materials of a scientific seminar «Modern problems of development». World economy and the international relations, 8, 69-81. 
Faber, M. (2008). How to be an ecological economist. Ecological Economics, 66, 34-46.

Faskhutdinov, A. (2015) Modernization of the Russian economy in terms of innovative development. Procedia - Social and Behavioral Sciences, 210, 188-192. https://doi.org/10.1016/j.sbspro.2015.11.358.

Fedotova, V. G. (2009). Rossiyskaya istoriya v zerkale modernizatsii [The Russian history in a modernization mirror]. Voprosy filosofii - Philosophy questions, 12, 3-18 [in Russian].

Gracheva, E. Yu. (2011). Pedagogicheskaya internatura v razvitykh stranakh mira [Pedagogical internship in the developed countries of the world]. Retrieved from http://www. rusnauka.com/28_PRNT_Pedagogica/2_94004.doc.htm [in Russian].

Guriev, S., Plekhanov, A., \& Sonin, K. (2010). Ekonomicheskiy mekhanizm syr'evoy modeli razvitiya [The economic mechanism of the raw material development model]. Voprosy ekonomiki-Issues of economics, 3, 4-23 [in Russian].

Indexes of physical volume of gross national product without an exception of the seasonal factor (\% by corresponding quarter of previous year). (2018). Federal Agency of the state statistics. Retrieved from http://www.gks.ru.

Jasiak, A. (2015). Ergonomic modernization in a selected automotive company. Manufacturing, 3, 47694775. https://doi.org/10.1016/j.promfg.2015.07.578.

Krasilshchikov, V. A. (2009). Modernizatsiya: Zarubezhnyy opyt i uroki dlya Rossii [Modernization: foreign experience and lessons for Russia]. In V. L. Inozemtsev (Eds.), Modernizatsiya Rossii: usloviya, predposylki, shansy. Strategicheskie problemi modernizatsii [Modernization of Russia: conditions, preconditions, chances. Strategic problems of modernization] (pp. 85-160). Moscow: Tsentr [in Russian].

Kryuchkov, V. A., Skovikov, A. K., \& Shumilova, O. V. (2014). Zarubezhnyy opyt politicheskogo razvitiya obshchestva (po materialam arkhivnykh dokumentov) [Foreign experience of political development of a society (on materials of archival documents)]. Sovremennye problemy nauki i obrazovaniya Modern problems of a science and education, 4. Retrieved from http://www.scienceeducation.ru/ru/article/view?id=13948 [in Russian].

Kryuchkov, V. A., Skovikov, A. K., \& Titova, O. N. (2013). Politicheskaya elita: teoreticheskiy aspect [Political elite: theoretical aspect]. Fundamental'nye issledovaniya-Basic researches, 11(8), 1736-1740 [in Russian].

Kutsenko, O. D. (2004). Fazy ta shliakhy systemnykh peretvoren: podibnist ta vidminnist u postsotsialistychnii ekonomitsi [Phases and ways of system transformations: similarity and distinctions in postsocialist economies]. In Postkomunistychni peretvorennia: vektory, napriamky, pidtrymka [Postcommunist transformations: vectors, directions, the maintenance] (pp. 418-423). Kharkov: KhNU of V.N. Karazina [in Ukrainian].

Lanskoy, G. N. (2018). Mezhdunarodnyy opyt modernizatsii dlya Rossii [The international experience of modernization for Russia]. Retrieved from http://rodnaya-istoriya.ru/index.php/rossiya-v-mirovix- 
processax/status-i-gosudarstvenniie-imidj-rossii-v-mejdunarodnoie-srede/mejdunarodniie-opitmodernizacii-dlya-rossii.html [in Russian].

Lavrov, E. A., Vodolazskaya, N. V., Pasko, N. B., \& Krivodub, A. S. (2015). Komp'yuterizatsiya ergonomicheskoy podgotovki inzhenernykh kadrov APK [Computerization of ergonomic training engineering personnel agrarian]. Innovatsii v APK: problemy i perspektivy - Innovations in agrarian: problems and prospects, 1(5), 12-18.

Maksimova, L. A., \& Lyamtseva, L. V. (2011). Rossiyskaya modernizatsiya (terminologicheskie aspekty) [The Russian modernization (terminological aspects)]. Sovremennye problemy nauki i obrazovaniya - Modern problems of science and education, 5. Retrieved from http://www.scienceeducation.ru/ru/article/view?id=4822 [in Russian].

Margolis, A. A., \& Rubtsov, V. V. (2011). O strategii i napravleniyakh modernizatsii pedagogicheskogo obrazovaniya $v$ Rossii: analiz mezhdunarodnogo opyta podgotovki uchitelya k novoy shkole [About strategy and directions of modernization of pedagogical education in Russia: the analysis of the international experience of training of the teacher for new school]. In Psikhologo-pedagogicheskoe soprovozhdenie natsional'noy obrazovatel'noy initsiativy "Nasha novaya shkola» [Psychological pedagogical maintenance of the national educational initiative "Our new school»] (pp. 47-67) [in Russian].

Matokhina, A. V., Kizim, A. V., Skvaznikov, D. E., \& ect. (2017). Development of the Intelligent Platform of Technical Systems Modernization at Different Stages of the Life Cycle. Procedia Computer Science, 121, 913-919. https://doi.org/10.1016/j.procs.2017.11.118.

Melitek catalog. Retrieved from https://www.melytec.ru/production/.

Meshkov, A. V., Bondareva, I. A., \& Vodolazskaya, N. V. (2018). Aktual'nye voprosy vzaimosvyazi tekhnicheskoy i ekonomicheskoy podgotovki studentov $\mathrm{v}$ usloviyakh sovremennoy sistemy obrazovaniya [Important questions of interrelation of technical and economic training of students in the conditions of a modern education system]. In Aktual'nye problemy agraroinzhenerii $v$ XXI veke [Actual problems agri-engineering system in the XXI century] (pp. 582-586). Belgorod: BSAU [in Russian].

Meshkov, A. V., Bondareva, I. A., \& Vodolazskaya, N. V. (2017). Geoekonomicheskie aspekty gazoobespecheniya evropeyskogo rynka [Geoeconomic aspects of gas supply the European market]. In Resursosberezhenie, effektivnost', razvitie [Cost-effective use of resources, efficiency, development] (pp. 190-194). Donetsk: DonNTU [in Russian].

Minyurova, S. A. (2015). Global competence as effect of realization of cultural-educational projects. Pedagogical education modernization in a context of the global educational summons, 167-170.

Pain, E. A. (2008). Historical «run on a circle» (attempt of an explanation of the reasons of cyclic failures of modernization processes in Russia. Social studies and the present, 4, 5-20.

Federal'naya sluzhba gosudarstvennoy statistiki [Federal State Statistic Service]. (2018). Retrieved from http://www.gks.ru/wps/wcm/connect/rosstat_main/rosstat/ru/statistics/. 
Sharaya, O. A., \& Vodolazskaya, N. V. (2018). Ispol'zovanie aktivnykh metodov obucheniya pri podgotovke agroinzhenerov [Use of active methods of training by preparation of agroengineers]. In Integratsiya nauki, obrazovaniya i proizvodstva - osnova realizatsii Plana natsii [Integration of a science, formation and manufacture - a basis of realisation of the Plan of the nation] (pp. 307-309). Karaganda: KarSTU [in Russian].

Shmyrova, N. V. (2010). Modernizatsiya rossiyskoy ekonomiki i osnovnye puti ee osushchestvleniya v sovremennyy period. Ekonomicheskie nauki [Modernization of the Russian economy and the basic ways of its realization to the modern period. Economic sciences]. Vestnik of Lobachevsky State University of Nizhni Novgorod, 3(2), 639-643 [in Russian].

Simonova, A. A., \& Minyurova, S. A. (2015). Effekt modernizatsii pedagogicheskogo obrazovaniya v kontekste pozitsionirovaniya vuza [Effect of modernization of pedagogical education in a context of positioning of high school]. Pedagogicheskoe obrazovanie $v$ Rossii - Pedagogical education in Russia, 12, 17-24 [in Russian].

Soderbaum, P. (2008). Understanding Sustainability Economics: Towards Pluralism in Economics (pp. 109-117). https://doi.org/10.4324/9781849773638.

Steiner, X. (2003). Differences and similarity in social realities: the Sociological analysis of Russia in comparison with Poland and Hungary. Sociology: the theory, methods, marketing, 4, 191-206.

Sztompka, P. (1994). Sociology of social changes. Aspect the Press, 16, 1-7.

Rossiyskaya modernizatsiya: problemy i perspektivy (Materialy kruglogo stola) [The Russian modernisation: problems and prospects]. (1993). Voprosy filosofii - Philosophy questions, 7, 3-39 [in Russian].

Victor, P. (2008). Frontiers in Ecological Economic Theory and Application. Ecological Economics, 66, 57-71.

Vodolazskaya, N. (2009). Models of network planning and management of power- consuming industries. Application of newtechnologies in management, 2, 811-818.

Vodolazskaya, N. (2012). Application internal marketing as means of rating increase educational institution and improvement of quality of educational services. In Quality, Management, Environment, Education, Engineering (pp. 357-361).

Vodolazskaya, N. (2016). To a question of providing a sustainable development of regional production systems of various level. Wspólpraca Europejka, 8(15), 64-70.

Vodolazskaya, N. V., \& Strebkov, S. V. (2017). Nadezhnost' i ekspluatatsiya tekhnicheskikh sistem [Reliability and operation of technical systems]. Belgorod: BSAU.

Vodolazskaya, N. V. (2011). Nekotorye aspekty podgotovki upravlencheskikh kadrov dlya energoemkikh predpriyatiy [Some aspects of training of administrative professional managers for the powerintensive enterprises]. In Kachestvo obrazovaniya-upravlenie, sertifikatsiya, priznanie [Quality of formation - management, certification, a recognition] (pp. 207-214) [in Russian]. 
Vodolazskaya, N. V. (2012). Feature of marketing strategy in sphere of modern educational services. The East European magazine of high technologies, 1(13(55), 27-29.

Vodolazskaya, N. V. (2016). Sovershenstvovanie sistemy TOiR za schet povysheniya nadezhnosti ispol'zuemoy remontnoy osnastki [Perfection of system of vendor recommended maintenance at the expense of increase of reliability of used repair equipment]. In Problemy $i$ perspektivy innovatsionnogo razvitiya agrotekhnologiy [Problems and prospects of innovative development of agrotechnologies] (pp. 21-22) [in Russian].

Vodolazskaya, N. V. (2017). About tendencies of a sustainable development of regional industrial systems [O tendentsiyakh ustoychivogo razvitiya regional'nykh proizvodstvennykh sistem]. In Problemy i resheniya sovremennoy agrarnoy ekonomiki [Problems and decisions of modern agrarian economy] (pp. 186- 187) [in Russian].

Vodolazskaya, N. V. (2017). Problem of competitiveness of higher education in system of the international cooperation. In Modern society cooperation and partnerships (pp. 31-35).

Vodolazskaya, N. V. (2018). Innovatsionnyy podkhod k obespecheniyu ustoychivogo razvitiya organizatsionno-ekonomicheskikh sistem [Innovative approach to sustainable development maintenance organizational - economic systems]. In Organicheskoe sel'skoe khozyaystvo: problemy i perspektivy [Organic agriculture: problems and prospects] (pp. 51-53) [in Russian].

Vodolazskaya, N. V. (2018). Modelirovanie tekhnicheskikh system dlya povysheniya nadezhnosti vypuskaemoy produktsii [Modelling of technical systems for increase of reliability of let out production]. In Organicheskoe sel'skoe khozyaystvo: problemy i perspektivy [Organic agriculture: problems and prospects] (pp. 196-198) [in Russian].

Vodolazskaya, N.V., Bondareva, I. A. (2016). O nekotorykh aspektakh innovatsionnykh protsessov v sisteme sovremennogo obrazovaniya [About some aspects of innovative processes in system of modern education]. In Innovatsionnye protsessy $v$ sotsial'no-ekonomicheskom razvitii [Innovative processes in social and economic development] (pp. 22-24) [in Russian].

Zencey, E. (2005). Mr. Soddy's Ecological Economy. Green Economy, 54, 457-501. Retrieved from http://www.nytimes.com/2009/04/12/opinion/12zencey.html?_r=3\&pagewanted. 